\title{
Traditional Agroforestry Ecosystem for Rural Prosperity
}

\author{
Carolina Carolina ${ }^{1 *}$, and Febtri Wijayanti ${ }^{2}$ \\ ${ }^{12}$ Research Center for Science Technology and Innovation Policy and Management \\ Indonesian Institute of Sciences
}

\begin{abstract}
Pursuance of prosperity has always been the aim of rural development program. A strategy to vitalizing rural economy to ensure equitability is achieved through optimal utilization of local resources. It is an inclusive approach, widely implemented which also applied in Indonesia. In order to examine the concept, a qualitative study was conducted in Sumba Barat Daya in East Nusa Tenggara Province, in which agriculture is the leading sector of regional development. Assessment is focussed toward the potency of natural resource, specifically traditional agroforestry system, producing variety of estate crops which are sold in local, regional and international market as well. Representing different type of market system, assessment on cashew and coffee crops were discussed. The analysis indicates that potency to achieve prosperity seems more promising when the strategy implemented is local driven. We encounter that farming activity in managing coffee based agroforestry generates local innovation, not just in ecosystem management, but also in post harvest handling and local market system establishment. Therefore, management of coffee agroforestry leads better to inclusivity in comparison with cashew. However, to ensure sustainable support of traditional agroforestry ecosystem to rural livelihood, understanding socio-ecological dynamics of rural Sumba should be acquired in order to generate supportive relevant policies.. yamu,to,
\end{abstract}

\section{Introduction}

Amidst many obstacles found in the policy enactment (Long, 1987; Knickel et al., 2017; Soleh, 2017) rural development has been implemented as one of strategy to reduce inequality in many countries. Indonesia declare the importance in Law no 6/2014 on Village Development programs in which prosperity is stated as the goal. Similar in goal 6 of Sustainable Development Goals, indicating that it is not just a local quest but a globally significant pursuit. The fact that approximately $45 \%$ of Indonesia's population live in rural areas, where most of the poor abide is a strong motivation to always strive for betterness thorugh rural development strategy. The policy accomodates diversity of ideas being implemented as every regions may have different characters to cater, implying that

\footnotetext{
*Corresponding author: carolina.4q@gmail.com
} 
understanding rural sosio-ecological system is necessary in order to obtain appropriate approach of rural development (Schouten et al., 2009)

Rural development to achieve people's prosperity has undergone transformation from considering economy as sole factor of progress and modernisation to present nuance of balancing economic, social and environment consideration as sustainable procurement (Rivera, et al., 2018) Nevertheless it indeed requires multidimensional thinking to contextualize prosperity as goal of rural development, a strategy that should be designed for equal distribution of wealth within society and areas (Pouw \& Gupta, 2016). As a long known environmental management practice, agroforestry provides wide range of opportunities for farmers to gain sustainable benefits (Nair, 1991; Liu et al., 2014; Leakey, 1996) recognize it as a globally important ecosystem that will remain important in the long run due to its capacity to support livelihood, and provide environmental benefits as well. Being traditional, its sustainable optimal ecosystem service is known to be supported by local knowledge (Nair, 1991), an important assets to vitalize rural economy.

As agrarian base region, Indonesia's strategy of rural development consider local resources as important assets to achieve the mission. In this study, we explore the strength of traditional agroforestry system in support to rural economic activity on the assumption that utilization of local resources will be the most approachable strategy.

\section{Methodology}

\subsection{Study Area}

The study was conducted in Sumba Barat Daya in East Nusa Tenggara Province, an agrarian region as most of many areas in Indonesia. Ecologically, it is a part of Sumba Island in East Nusa Tenggara Province Indonesia (Figure 1). About 331.894 people lives in an area of $1.445,32 \mathrm{~km} 2$, confirming the region as the most populated district in the island. Among them, $70 \%$ work at agriculture sector to include agroforest management (Statistics, 2018). Landuse can be chategorized into wet land and dryland, which are $12.3 \%$ and $46.2 \%$ of total 72,057 Ha. respectively. In agroforestry ecosystem management, they plant various species of trees for subsistence and also commercial purpose. Sumba Barat Daya region consists of 11 subdistricts i.e. Kodi Bangedo, Kodi Balaghar, Kodi, Kodi Utara, Wewewa Selatan, Wewewa Barat, Wewewa Timur, Wewewa Tengah, Wewewa Utara, Loura, and Kota Tambolaka. Socio-culturally the area is divided into three different parts i.e. Kodi, Wewewa and Loura. Kodi and Wewewa differs in ecosystem and language spoken; whereas Laora is occupied by mixture of cultures to include immigrants from outer island.

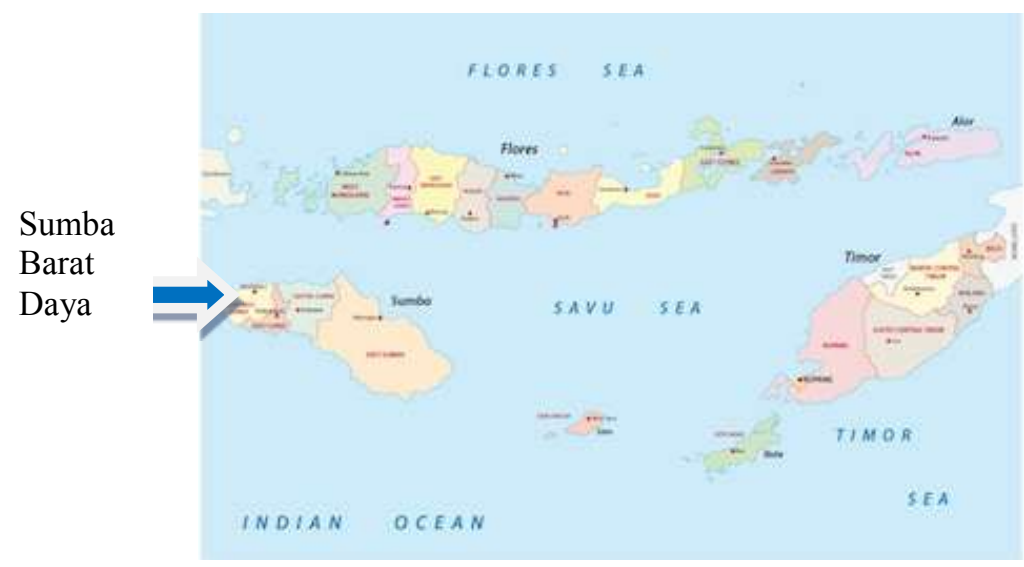


Fig. 1. Map of East Nusa Tenggara Province

(Source:www..shutterstock.com)

\subsection{Research Method}

Agroforestry is recognized as an important traditional land use practice, due to its high levels of biodiversity, traditional knowledge systems, livelihood support system, diversified traditional cultures and its undoubtly economic value (Leakey, 1996; Mercer et al., 2014; Njurumana, 2014; Rivera, et al., 2018). This study focuses on the role of traditional agroforestry as livelihood support to rural community under the assumption that the ecosystem develop overtime by the support of local knowledge (Nair, 1991). The years experience in managing the landuse currently resulted as a system capable of supporting not only subsistence need but also a steady source of family income. Ecosystem management and socio-economic situation interactively connected (Hou et al., 2014), in reality establishment of local market could be resulted by landuse system productivity (Beder, 2011).

To examine the relevance of agroforestry management in rural prosperity, we conducted this study which is designed as a qualitative research to allow understanding of complex reality (Cresweell, 2014) and further analysed amenably. Collection of primary data is conducted by means of in-depth interview to informants i.e head of village, senior farmers, government officers from agriculture sector. We also conducted 2 focus group discussions with coffee and cashew farmers. Secondary data is obtained from local and national statistical office; and also from relevant local government office.

We also use Location Quotient analysis in order to determine comparative advantage of commodities. Commodity with LQ $>1$ indicates that the commodity is considered as basic commodity and has comparative advantage which is supported by natural resources, a lack in other area (Jawang, 2018). Value of LQ $<1$ means the commodity can not be considered as basic commodity. LQ equation is as follows :

$$
L Q=P i / P t / P . i / P . t
$$

Notes :

$\mathrm{Pi}=$ commodity production share at sub-district level

$\mathrm{Pt}=$ commodity production share at district

P.i = total commodity at sub-district level

P.t $=$ total commodity at district level

\section{Result and Discussion}

\subsection{Traditional agroforestry ecosystem : distribution and productivity}

As a traditional land use practice in various socio-ecological system, agroforestry land management is also observed in Sumba Barat Daya. Approximately $47 \%$ of agricultural land is dedicated to polycultures of trees and food crops which are planted on the same area at the same period, or differ in time. In general, 13 species of trees grow in agroforest and produce significant quantity of yield. Among those, production of cashew (Anacardium occidentale L.) coconut (Cocos nucifera L.), coffee (Coffea canephora), areca-nut (Areca catechu L.), and Cocoa (Theobroma Cacao) are the five highest (Table 1) 


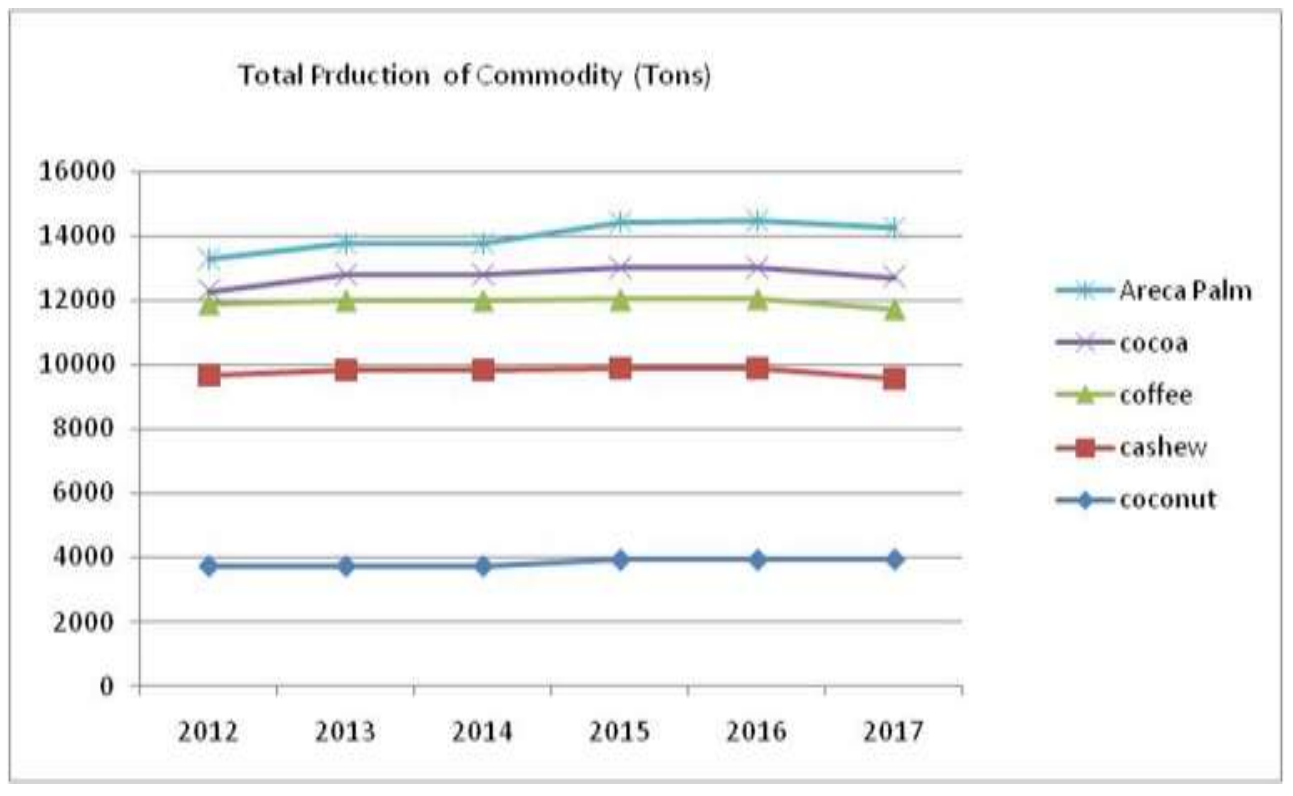

Fig. 2. Total Production of Commodity (2012-2017)

As indicated by Figure 1, there is no significant fluctuation of yields experienced during the period of 2012-2017. It does show stability of productivity although climatic change is not to be ignored. Uniquely distributed, the plants grow in agroforest cropping system in many areas which could be characterized by socio-ecological condition. Except cashew and coconut that are cultivated in plane dry area of Kodi, the other crops grow in higher altitude areas of Wewewa. What is similar is farmer's consideration to the land use as livelihood support they could rely upon. To some extent, the high productivity gives brand to the village and allure buyers to come fetching the produce.

In confirmation of the productivity data above, we performed Location Quotient Analysis . It is necessary to show the strength of certain subject in an area in relevant with a larger area (Tarigan, 2007). In our study, the subject is commodity planted in agroforestry system. The higher LQ, the more comparative the subject is. The analysis usually utilized as a means to identify Produk Domestik Regional Bruto because choosing the right basic commodity will help economic growth of a region. Table 1 show the results of analysis and confirm that cashew, coconut, coffee, arecanut and candlenut are categorized as basic commodity. 


\begin{tabular}{|c|c|c|c|c|c|c|c|c|c|c|c|c|c|}
\hline Eeromete & $\cos \theta=0$ & conter & ctiter & actis & rotent & thel & dre & $\begin{array}{l}\text { Muter } \\
\text { pate }\end{array}$ & Kanle & Ellatep & Chine & Thenerse & Band \\
\hline Iodi bangedo & 1.1858 & 1.179 & 02599 & 2848 & 0.3413 & $131 \% 5$ & 0.1219 & 0.3455 & 0.837 & 3.874 & 05868 & 0.9826 & n7446 \\
\hline Iodi Balaghar & $\mathrm{n} 4527$ & 25382 & nnc8 & 0.325 & 0.1848 & a.min & a.mon & a.m68 & amon & 00268 & 02146 & 0.4191 & an134 \\
\hline Tod & 18509 & 1.7191 & n.3248 & $0.06 / 2$ & 0.0093 & 0.015 & ams & 0.1009 & a.mon & 00019 & anom & 00261 & an243 \\
\hline Iodi Utara & n6786 & 3.1310 & n0186 & 0.2134 & D.nIEs & $\mathrm{a} . \mathrm{m} n$ & a.mo & a.mits & a.mon & Dons1 & 0000 & DOAGO & ano338 \\
\hline Wewewa Selatan & 1 ARA & nn951 & $1.1 \mathrm{~m}$ & a.zng1 & D.6A9 & a.man & 0.957 & 05646 & 0.0559 & onomo & 0000 & 00028 & nong9 \\
\hline \begin{tabular}{|l|} 
Wewewa Barat \\
\end{tabular} & 1003 & nnag4 & 15555 & 0.3159 & 0.748 & a.mas & D.0161 & 0.2145 & a.mas & anzas & anon & 00327 & 00442 \\
\hline \begin{tabular}{|l} 
wewewa Thur \\
\end{tabular} & n78999 & nmono & 13365 & 0.518 & 1.107 & 0.053 & a.m16 & 0.1769 & a.m26 & ango & anmo & 00038 & 00379 \\
\hline Wewewa tengah & 05701 & nnom & 05998 & $0.20 \pi$ & 0.4416 & a.mos & a.m31 & $1 \mathrm{~m}$ & a.m32 & DOMOO & anom & 00013 & 02669 \\
\hline Wewewa Ltara & n6615 & 01405 & 05256 & 0.2179 & a.7ns8 & D.MA5 & 0.71乃 & 15 ses & a.m.36 & 00036 & 00000 & 00136 & nn680 \\
\hline Loura & nக્53 & 25755 & 01545 & 0.058 & a.mon & a.m29 & a.m32 & 0.580 & amon & 00322 & 00000 & DOMOO & n1ma30 \\
\hline Iota tambolaka & n万562 & 32597 & nomon & a.nom & D.1890 & a.m27 & amon & a.mon & a.mon & anom & 00000 & DOMOO & anono \\
\hline
\end{tabular}


The result also shows that basic commodities in every area is different from one another, and there are similarities among regions. In summary, it is presented in Table 2 as follows.

Table 2. Summary of Basic Commodities in Sub Districts

\begin{tabular}{|c|c|}
\hline Sub District & Basic Commodities (LQ>1) \\
\hline Kodi Bangedo & cashew, coconut, cocoa, kapok, jathropha \\
\hline Kodi Balaghar & cashew \\
\hline Kodi & cashew, coconut \\
\hline Kodi Utara & cashew \\
\hline Wewewa Selatan & coffee, coconut \\
\hline Wewewa Barat & coffee, coconut, candlenut \\
\hline Wewewa Timur & areca-nut \\
\hline Wewewa Tengah & areca-nut \\
\hline Wewewa Utara & cashew \\
\hline Loura & -none- \\
\hline Kota Tambolaka & col \\
\hline
\end{tabular}

In summary, results of LQ analysis confirms that Kodi is high producing cashew nuts and also coconut, suggesting that further development could be started from those commodities, whereas Wewewa agroforest is predominantly cultivated by coffee and areca nut.

Table 3. Characters of Kodi and Wewewa Area in Sumba Barat Daya

\begin{tabular}{|c|c|c|}
\hline & Kodi & Wewewa \\
\hline Topography & Mostly plane & Slope \\
\hline Altitude & $\begin{array}{c}0-300 \text { m above sea } \\
\text { level }\end{array}$ & $\begin{array}{c}350-800 \mathrm{~m} \text { above sea } \\
\text { level }\end{array}$ \\
\hline Cropping System & monoculture & Polyculture \\
\hline & $\begin{array}{c}\text { Intercrop with } \\
\text { foodcrop in rainly } \\
\text { season }\end{array}$ & $\begin{array}{c}\text { No additional crop } \\
\text { temporally }\end{array}$ \\
\hline Dominant crops & cashew, coconut & $\begin{array}{c}\text { coffee, areca nut, } \\
\text { candlenut }\end{array}$ \\
\hline
\end{tabular}

This study was conducted in 2 villages to represent coffee and cashew based areas, i.e. Kadi Roma village in Central Wewewa and Kalaki Kambe village in West Wewewa respectively. Moreover, the areas were selected because of accessibility reason, and also availability of all aspects needed to be explored in order to attain representative situation 


\subsection{Local Innovation of Land Management}

This study examines the role of traditional agroforestry as livelihood support to rural community. Agro forestry is an old land use practice worldwide which has shown strong resilience over centuries and attains global importance (Liu et al., 2014). It is an indispensable land management system due of its high levels of biodiversity, local knowledge systems, livelihood guarantee and diversified traditional cultures. Local farmerdriven innovations becomes an important support of sustainability, especially since farmers incline to efficiently using the resources available to them. The years experience in land use management resulted as an ecosystem capable of supporting not only subsistence need but also a steady source of family income. Management system of dry land as agroforestry can be distinguished as two distinctive ecosystem i,e, traditional agroforestry in Wewewa, called kalio, situated in higher altitude of 350-800 m above sea level and agroforestry system in Kodi, called mango, which is located in plane area. The distinctiveness as indicated in Table 2 show that dominant tree species differs. Kalio in Wewewa is dominated by coffee, whereas mango in Kodi is by cashew.

Although the two main species planted in similar system, i.e agroforestry, cashew and coffee planting have different ecological history. Cashew was introduces through IFAD program in the 1980 's, altering high diversity forest to become almost monocrop system. It was part of rural poverty alleviation. Cashew was preferred due to its ability to grow optimally in semi-arid land. Short rainfall season as occur in Sumba is not a limitation for cashew to grow healthily. Over the time, local people adapt the presence of cashew plantation by planting food crops during rainy season. After crop harvest time, they use empty space for herding pigs and chickens, and let them find food in the environment. With the strategy, they will have corn, peanuts, and in many areas, dryland paddy, and healthy pigs. Thus by planting cashew based agroforestry, it enables farmers to develop silvopastoral system.

Unlike cashew plantation, coffee was introduced around 5 decades ago by Timorese, not intentionally introduced by a project. Starting as one of many kinds of tree species planted in kalio, it is now become dominant tree in most of agroforestry system managed. At present coffee plays important role as source of family income, also as a commodity with high social value. Unlike cashew planting system, coffee in kalio is planted with many other tree species with variety of purposes (Carolina, 2016). Fruitcorps and also starchy crops planted in the same area at the same period. They implement a low external input strategy in maintaining the plots without any plant rotation system. Quantitatively, their sole dependence on local innovation over time resulted in present condition that is low productivity of coffee in comparison with national average; however further exploration on ecosystem management need to be performed in order to gain better understanding of the phenomenon.

In general, it is safe to say that the dynamics of agroforestry management predominantly planted with cashew and coffee is to some extent maintained by the establishment of local market, where produce will be readily exchanged with currency. Rural people take the most advantage of existing market whilst caring for the crops to continuously producing as expected.

\subsection{Marketing System of Agroforestry Products}

Most of produce sold by farmers follows traditional market system. Farmers direct connections is developed with local buyers who provides cash as exchange to their harvest. Regardless of the fact that coffee and cashew have global value, local market system is still the one they rely upon. Coffee market system is depicted in Figure 3. 


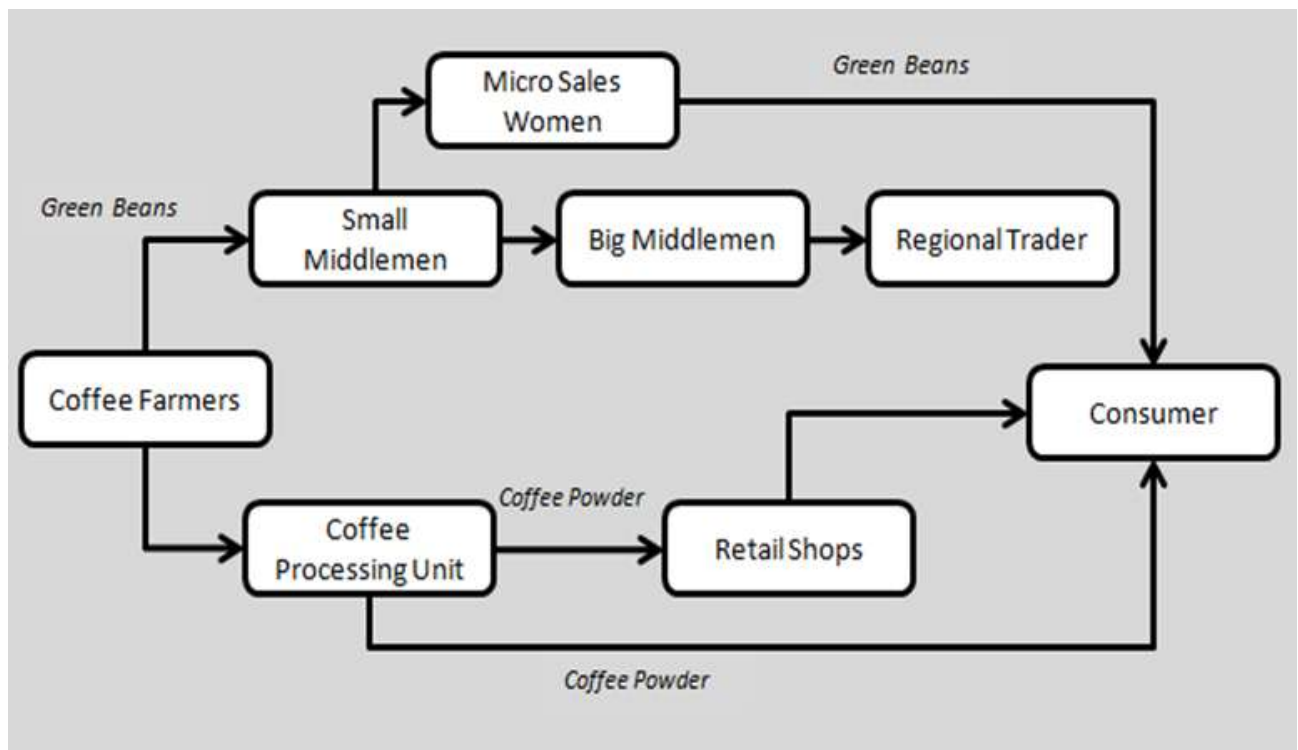

Fig. 3. Coffee market system

Harvest time is the period of farmers processing their coffee bean to become green bean. They will store the green bean for sometimes if not cashing it all directly when currency is needed. Coffee creates many types of sales, all integrated in local market system. From small middlemen (called "popolele"), who are mostly establish direct relation with farmers, to midsize middlemen who collect coffee greanbeans from several small buyers, they also have microsaleswomen called "mamamok" who sells greenbeans in mugs. It is an interesting market system that provide opportunity for many people to take "a pinch" of profit from their business. They call it "profit sharing for many". There are indeed bigsize buyer or middlemen or "popolele besar" who establish connection to send green beans to other region.

Coffee farmers also have oopportunity to sell their product to coffee processing units. Although the quantity needed is small compare to a village productivity, the unit has potency to become an effective part of village market system of local coffee.

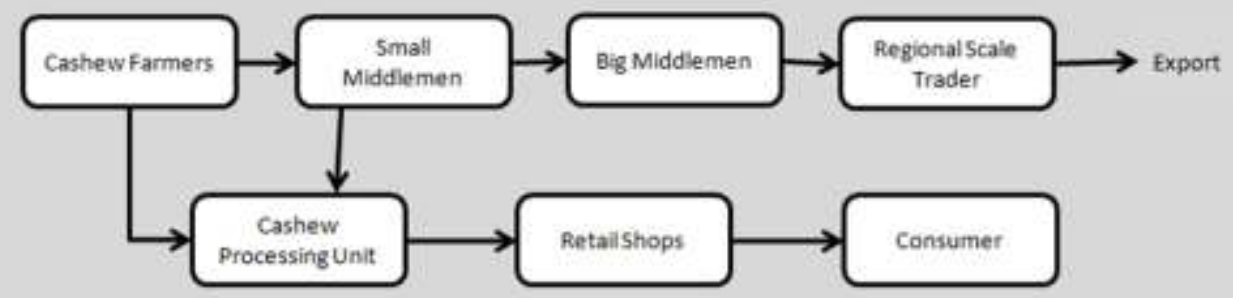

Fig. 4. Cashew market system

Cashew market system is less complicated because it is not a product they consume daily. A complicated processing technology and also the high sales price of raw cashew motivate them to sell rather than consume. Middlemen in cashew market system work 
based on free competition, although there are different levels of middlemen actively taking part in the supply chain. Small middlemen reside in villages, whereas bigger one cover more than one village. They collect the product up to certain quantity before selling it to commodity trader which directly connected with big companies dealing with export goods. Unlike the case of coffee market system, cashew market chain confirms that farmers as producers is an isolated entity who may loose opportunity to gain fair share of their work.

Although coffee and cashew are considered as global commodities, farmers have no direct access. Being smallholders, their traditional management is not only applied in caring for the plant and plantation, but also in marketing the product. As smallholder farmers, fulfilling subsistence need is their main concern. It is expressed by the way they sell the product. Unaware of the high value of crops, farmers usually sell in small portion, enough to have money for couple of days life. Only at certain occassion, they do sales in bigger quantity, although by global-scale business standard, it is still considered far from sufficient. By doing so, farmers only receive small amount of margin.

In reference on how farmers establish capability to manage the ecosystem, from crop planting to harvest the produce, and successfully partaking on the market system, we envisage a better scheme to increase not only the margin received but also bargaining power in the market. In order to meet global standard, a strategy need to be developed aiming at supporting and protecting the well being of rural community. However the idea should be carefully implemented not to cause certain parties being left out. One approach to accomplishing this for the small farmer is through the development and running of cooperatives and appropriate supply chains (Jang \& Klein, 2011). Direct sales to small middlemen place the farmers in uncertain situation. They do not have access to price information, and give in to market fluctuation scenario played by the middlemen. Creation of off farm economic activities based on local products will be a advantageous. However, both crops retain different characters to be carefully referred. Based on series of field activities performed with coffee and cashew farmers in two different villages, we could derive a conclusion that is not difficult to transfer processing technology, what is challenging is to establish an attitude of technology application to produce standardize product.

However, it is a challenge worth taking when we aim at achieving rural prosperity. Appropriate supports should be provided, not only in part of increasing land productivity through strengtheing local knowledge, but also providing support in technology advancement and marketing system (Molua, 2005). The efforts should be designed to attain value add shared in equity.

\subsection{Rural Development Program : In reality}

The potential of agroforestry as support to livelihood is found in many areas such as Malawi, Bangladesh (Ndalama et al., 2015; Hanif et al., 2018) although socio-ecological hindrances to success are unavoidably found (Hanke et al., 2017). Evidence from the case studies conducted in two villages namely Kadi Roma and Kalaki Kambe, representing predominantly coffee and cashew agroforestry are potential to be reffered as local natural resources assets for rural development program. However, the idea of promoting local natural resource is not in the agenda. Farmers, who are the managers of ecosystem, seems to think, work, and act alone. There seems no connection between village authorities, nor local government officers from relevant sector. Crop cultivation in rural ecosystem obviously an expression of local-driven-innovation materializing from long experience in managing the environment. Crop handling and processing technology implemented are mostly traditional, sufficient to meet the local market standard. Efforts to enhance level of 
technology acquired was initiated by local government program but lacking in continuous assistance to establish sustainable capacity.

The fact that Act 6/2014 recommend optimal use of local resources by means application of appropriate technology is not well translated to reality. Although the concept is confirmed by LQ analysis, acknowledgement to potency of local resource specifically the local driven innovation i.e. agroforestry ecosystem is not a concern. Although specialization in one of the main resources can boost inequality of development between regions (Hidayat, 2014), as local economy and social assets, it worth promoting (Zega et al., 2013). Inequality can be avoided by establishment of a strategy to enhance value of local products and create linkage among sectors to ensure shared benefits across rural regions (Hidayat, 2014).

The starting points of major mismatch between visions and reality may be due to limited capacity of local village rulers to interpret Act 6-2014. Socialization and assistance from their superior direct them to focus on infrastructure development such as rural roads and the like. Its lack of thorough understanding of the opportunity provided by rural development policy measures will lead them to missing the prospect of achieving condition of just prosperity

\section{Conclusion}

In reference to the ecosystem potency, it is concluded that socio-ecological innovation stemmed from agroforestry ecosystem in pursue of rural prosperity might be achieved by means of nurturing local innovation system as valuable assets to development i.e. technology of agroforestry ecosystem management to include seed selection, plant, maintenance, harvest; institutionalizing local market system to ensure fair share of benefit accross rual community; promotion of collective action in many aspects of activities i.e. agroforestry resource management, post harvest technology, sales and marketing; enhancing the role of government to provide necessary supports to ensure sustainable rural development

\subsection{Acknowledgement}

This study is part of the work supported by National Priority Program "Appropriate Technology for Rural Economy Development based on Coffee Agroindustry in Sumba Barat Daya District 2019" conducted by Center for Appropriate Technology Indonesian Institute of Sciences. We thank our colleagues Mirwan A. Karim, Arie Sudaryanto who have provided great support to our field research and also Hari Siswoyo Aji who has constantly provided valuable insights.

\section{References}

1. S. Beder, Environ. Conserv. (2011)

2. Carolina. (2016). Peran strategis agroekosistem kopi rakyatdi Kabupaten Sumba Barat Daya Provinsi Nusa Tenggara Timur (The strategic role of smallholders coffee agroecosystem for South West Sumba District of East Nusa Tenggara Province). Jurnal Inovasi, 13, 65-74.

3. W. J. Creswell, Research Design. Qualitative, Quantitative, and Mixed Methods Approach, 4th ed. (United States: SAGE Publications, Los Angeles, 2014) 
4. M. A. Hanif, R. M. Roy, M. S. Bari, P. C. Ray, M. S. Rahman, and M. F. Hasan, SmallScale For. 17, 505 (2018)

5. H. Hänke, J. Barkmann, C. Coral, E. Enforskaustky, and R. Marggraf, Ecol. Soc. (2017)

6. M. Hidayat, Econ. J. Emerg. Mark. (2014)

7. Y. Hou, S. Zhou, B. Burkhard, and F. Müller, Sci. Total Environ. (2014)

8. W. Jang and C. M. Klein, Ann. Oper. Res. (2011)

9. U. P. Jawang, J. Pengelolaan Sumberd. Alam Dan Lingkung. (Journal Nat. Resour. Environ. Manag. 8, 396 (2018)

10. K. Knickel, M. Redman, I. Darnhofer, A. Ashkenazy, T. Calvão Chebach, S. Šūmane, T. Tisenkopfs, R. Zemeckis, V. Atkociuniene, M. Rivera, A. Strauss, L. S. Kristensen, S. Schiller, M. E. Koopmans, and E. Rogge, J. Rural Stud. (2018)

11. R. Leakey, Agrofor. Today 8, 5 (1996)

12. R. W. Long, Publius J. Fed. 17, 15 (1987)

13. F. W. Mercer, D. E., Frey, G.E. \& Cubbage, Handbook of Forest Economics (Earthscan from Routledge, New York, 2014)

14. E. L. Molua, For. Policy Econ. (2005)

15. P. K. R. Nair, For. Ecol. Manage. (1991)

16. E. Ndalama, G. Kamanga-Thole, and E. Missanjo, Int. J. For. Hortic. 1, 5 (2015)

17. G. N. Njurumana, D. Marsono, Irham, and R. Sadono, J. Mns. Dan Lingkung. (2014)

18.. N. Pouw and J. Gupta, Curr. Opin. Environ. Sustain. (2017)

19. M. Rivera, K. Knickel, I. de los Rios, A. Ashkenazy, D. Q. Pears, T. Chebach, and S. Šūmane, J. Rural Stud. (2018)

20. M. Schouten, M. Van der Heide, and W. Heijman, EAAE 113 Semin. Belgrade, Repub.

Serbia, December 9-11 (2009)

21. A. Soleh, J. Sungkai (2017)

22. R. Tarigan, Ekonomi Regional: Teori Dan Aplikasi (Bumi Aksara, Jakarta, 2007)

23. L. Weiwei, L. Wenhua, L. Moucheng, and A. M. Fuller, J. Resour. Ecol. (2014)

24. S. B. Zega, A. Purwoko, and T. Martial, Peronema For. Sci. J. 2, 157 (2013) 